\title{
Images and Figures
}

\section{Images}

Image 1 Photo taken by author beside Yellowknife City Hall. 6 Image 2 Giant Mine on the shores of Great Slave Lake. 61

Image 3 NWT Diamond Mines. 102

Image 4 Diavik Diamond Mine. 216

\section{Figures}

Figure 1 An expanded conception of production. 32

Figure 2 Percentage (\%) of territorial GDP by industry (2019). 130

Figure 3 Employment, by Class of Worker. Northwest Territories, 2001-2019. 130

Figure 4 Rates of employment. 133

Figure 5 Percentage of persons 15 and over who trapped in a given year, by region, Northwest Territories, 1988-2018. 188

Figure 6 Percentage of persons 15 and over who hunted or fished in the year, by community, Northwest Territories, 1998-2018. 189

Figure 7 Percentage of households where $75 \%$ or more (most or all) of the meat or fish eaten in the household, by community, Northwest Territories, 1998-2018. 190 
This page intentionally left blank 